\author{
Горішня Катерина Іванівна \\ аспірант лабораторії соціальної психології особистості, \\ Інститут соціальної і політичної психології \\ НАПН України, \\ Київ, Україна \\ ORCID ID 0000-0002-4854-8126 \\ katerynag2016@gmail.com
}

\title{
СПОСОБИ ДІАГНОСТУВАННЯ ОСОБЛИВОСТЕЙ ПРОФЕСІЙНОГО САМОВИЗНАЧЕННЯ ВЕТЕРАНІВ
}

Статтю присвячено дизайну психодіагностичного дослідження чинників професійного самовизначення ветеранів АТО. Дослідження спрямоване на конструювання та апробацію батареї психодіагностичних методик з метою підтвердження або спростування дослідницьких гіпотез щодо доцільності використання дібраного інструментарію в масштабному емпіричному дослідженні. У дослідженні взяли участь демобілізовані учасники бойових дій, які виявили готовність до професійної переорієнтації та більш повної самореалізації. Емпіричну апробацію пройшли такі методики: “Тестопитувальник вимірювання мотивації досягнення” А. Мехрабіана (модифікація М. Магомед-Емінова), "Визначення толерантності до невизначеності" С. Баднера (модифікація Г. Солдатової), "Опитувальник посттравматичного зростання" Р. Тедеші та Л. Калхун (адаптація М. Магомед-Емінова), “Тест смисложиттєвих орієнтацій” Д. Леонтьєва. Емпірично підтвердили свою ефективність та в подальшому будуть використані в масштабному дослідженні такі методики: "Визначення толерантності до невизначеності” С. Баднера (модифікація Г. Солдатової), “Опитувальник посттравматичного зростання” Р. Тедеші та Л. Калхун (адаптація М. Магомед-Емінова), “Тест смисложиттєвих орієнтацій” Д. Леонтьєва. Виявлено, що на професійне самовизначення демобілізованого військовослужбовця значною мірою впливають соціально-психологічні чинники, зокрема толерантність до невизначеності, посттравматичне зростання та смисложиттєві орієнтації. Не підтверджено доцільність використання методики "Тест-опитувальник вимірювання мотивації досягнення" А. Мехрабіана (модифікація М. Магомед-Емінова). Дослідження має пошуковий характер і спрямоване на виокремлення та ретельний розгляд вагомих соціально-психологічних особливостей професійного самовизначення, які в подальшому доцільно враховувати в програмах соціально-психологічної адаптації демобілізованих учасників бойових дій для оптимізації процесу повернення їх до мирної праці та реадаптації. Дослідження являє собою оригінальний погляд на проблематику професійного самовизначення дорослої людини з урахуванням набутого травматичного досвіду та змін у світогляді.

Ключові слова: професійне самовизначення ветеранів; психодіагностика; мотивація досягнення; толерантність до невизначеності; посттравматичне зростання; смисложиттєві орієнтації. 


\title{
PSYCHODIAGNOSTIC METHODS OF VETERANS' PROFESSIONAL SELF-DETERMINATION FEATURES
}

\author{
Kateryna I. Horishnia \\ $\mathrm{Ph}$. D. Student of Laboratory of Social Psychology of Personality, \\ Institute for Social and Political Psychology, \\ National Academy of Educational Sciences of Ukraine, \\ Kyiv, Ukraine \\ ORCID ID 0000-0002-4854-8126 \\ katerynag2016@gmail.com
}

\begin{abstract}
The article is dedicated to the design of psychodiagnostic study of ATO veterans' professional self-determination factors. The research is aimed at projection and approbation of psychodiagnostic methods for confirmation or refutation of research hypotheses. Ukrainian ex-combatants took part in the research. Following methods passed the empirical approbation: "Test-questionnaire of achievement motivation measurement" by A. Mehrabian (modified by M. Magomed-Yeminov), "Diagnostics tolerance for uncertainty" by S. Badner (modified by G. Soldatova), "Posttraumatic Growth Inventory" by R. Tedeschi and L. Calhoun (adapted by M. Magomed-Yeminov), "Test of sense-life orientations" by D. Leontiev. According to the research results the effectiveness was confirmed in following methods"Diagnostics tolerance for uncertainty" by S. Badner (modified by G. Soldatova), "Posttraumatic Growth Inventory" by R. Tedeschi and L. Calhoun (adapted by M. Sh. Magomed-Yeminov), "Test of sense-life orientations" by D. Leontiev. The obtained results show significant influence to ex-combatants' professional self-determination of such socio-psychological factors as tolerance to uncertainty, post-traumatic growth and sense-life orientations. The expediency to use the "Testquestionnaire of achievement motivation measurement" by A. Mehrabian wasn't confirmed. The research has a scouting character and is aimed at searching of significant socio-psychological features which can be further used in forming and conducting of programs on socio-psychological adaptationof for ex-combatants in order to optimize the process of secondary professional self-determination and re-adaptation. The study represents an original view on the problem of adult's professional self-determination, taking into account the traumatic experience and changes in their worldview.
\end{abstract}

Key words: professional self-determination of veterans; psychodiagnostics; achievement motivation; tolerance to uncertainty; posttraumatic growth; sense-life orientations.

Постановка проблеми. Процеси мобілізації і демобілізації десятків тисяч учасників АТО, що відбуваються внаслідок тривалого воєнного конфлікту в Україні протягом останніх років, передбачають повернення військовослужбовців, які брали участь у бойових діях, до мирного життя. Українське суспільство має бути готовим до актуалізації нової ланки потреб демобілізованих, які виникли внаслідок їх безпосередньої участі у воєнному конфлікті. Незважаючи на те, що досвід війни $\epsilon$ травматичним для особистості, лише частина ветеранів анонсує свою потребу в психіатричній чи психотерапевтичній допомозі, тоді як більшість комбатантів потребують саме соціальнопсихологічного супроводу в процесі реадаптації до мирного життя. Суспільний запит щодо професійної реадаптації ветеранів є досить високим, як і особисті очікування демобілізованих військовослужбовців щодо пошуку себе в мирному житті. Розроблена державою програма допомоги у сфері працевлаштування досі показала себе недостатньо гнучкою, хоч і набула останнім часом більш системних рис. Питання поновлення на робочому місці або знаходження нової роботи є актуальним майже для кожного ветерана, який пройшов випробування війною. Віднайти себе у професійній діяльності в дорослому віці - це виклик, який несе в собі потенціал відновлення особистості. Дослідження соціально-психологічних чинників, які впливають на вторинне професійне самовизначення ветерана, має допомогти створити сприятливі умови для покращення його професійної та особистісної самореалізації. Виявлення способів сприяння особистісним змінам, спрямування на вибір та оволодіння новою професією може стати вагомим внеском у соціальнопсихологічну реабілітацію осіб, які не готові отримувати професійну психологічну допомогу після повернення із зони бойових дій, але хочуть брати участь у програмах, націлених на покращення якості життя ветерана. Готовність суспільства створювати умови для успішної реінтеграції забезпечує продуктивне долучення ветеранів до суспільних процесів та стає запорукою зменшення ризиків прояву алкоголізму та наркоманії.

Аналіз останніх досліджень і публікацій, невирішені частини загальної проблеми. Виконання будь-якої діяльності тісно пов'язане з мотивацією людини, з ії потребами, які створюють 
підгрунтя мотиваційного руху. Останнім часом мотивація досягнення широко досліджувалась в освітній сфері (Ю. Друзь, С. Моргунова, О. Хомік, М. Karaman), у контексті структури та психологічних корелятів (О. Віндекер), психічного здоров'я і патології (О. Тапалова, G. Fervaha), спонукання до лідерства (О. Тягунова).

Толерантність до невизначеності - один із викликів, який ставить перед особистістю сучасний світ та спонукає науковців до досліджень, пов'язаних проблематикою конструкта феномену (С. Литвин, М. Мельничук, В. Павленко), ідентичності (А. Гусєв), управлінської діяльності (О. Брюховецька), професійної компетентності (А. Гусєв, Н. Перегончук, С. Хілько),

Феномен посттравматичного зростання, як позитивний наслідок травматичних подій, усе більше привертає увагу фахівців, що спонукає до проведення емпіричних (S. Joseph, Д. Зубовський, F. LotfiKashani) i теоретичних досліджень цього соціально-психологічного феномену (Д. Зубовський, В. Осьодло, Г. Лазос, Т. Титаренко, О. Толкачева) в контексті соціальної підтримки (Д. Леонтьєв, А. Лєбєдєва, Т. Сілантьєва), підготовки методичних рекомендацій, спрямованих на оптимізацію супроводу (В. Климчук, А. Lianchao, П. Лушин, Т. Титаренко).

Смислове наповнення людської діяльності привертає увагу науковців до вивчення смисложиттєвих орієнтацій особистості, які наразі досить різнобічно досліджені в групах студентської молоді, передусім в аспектах становлення особистісної зрілості (О. Іванова, Г. Меднікова), динаміки (О. Москаленко), схильності до аутоагресії (О. Мусаелян) відкритості досвіду (П. Севостьянов), самоактуалізації (А. Харченко). Окрім того, смисложиттєві орієнтації досліджувалися у зв'язку 3 феноменами професійного вигорання (А. Густелева), релігійності (О. Двойнін), життєстійкості (М. Калашнікова), життєвих домагань (Т. Титаренко) та реадаптації до мирного соціуму (Н. Якушин).

Зазначимо, що в емпіричних дослідженнях професійного самовизначення дорослих людей комплекс вищезгаданих методик не використовувався.

Метою статті $\epsilon$ розроблення дизайну емпіричного дослідження вторинного професійного самовизначення ветерана та апробування психодіагностичних методик.

Теоретико-методологічною основою дослідження $є$ концепція розвитку особистості як активного суб'єкта власної життєдіяльності (О. Асмолов, Д. Леонтьєв, В. Татенко, Т. Титаренко), екзистенційно-гуманістичні підходи до самоактуалізації особистості (Е. Десі, А. Маслоу, Д. МакКлеланд, Р. Раян, В. Франкл, Е. Фромм, Х. Хекхаузен), теорія особистісного змінювання (П. Лушин), концепція посттравматичного зростання (Ф. Василюк, Л. Калхун, В. Климчук, М. Магомед-Емінов, Р. Тедеші, Т. Титаренко), концепція толерантності до невизначеності (С. Баднер, А. Гусєв, А. МакДональд, Е. Френкель-Брунсвік).

Виклад основного матеріалу дослідження. Реінтеграція ветерана до суспільного життя, що фактично розпочинається із залучення до мирної праці, може відбуватися як у формі повернення на своє робоче місце і до своєї колишньої професії, так і у формі пошуку нової роботи. Саме реінтеграція до професійної діяльності є одним із головних факторів адаптації, завдяки якому особа динамічно змінює військовий статус на цивільний, стає учасником суспільних подій, налагоджує міжособове спілкування, переймає цінності і норми навколишнього середовища та отримує фінансову винагороду за працю. Фінансова спроможність, яка є результатом повернення на робоче місце, позитивно впливає на емоційно-психологічний стан ветерана i допомагає йому пройти період пристосування до цивільного життя більш врівноважено, досягти стану психологічного комфорту, підвищити самоповагу та матеріальний добробут.

Професійне самовизначення людини, що має травматичний воєнний досвід, на нашу думку, суттєво відрізняється від професійного самовизначення в мирний час. Зміна професії в дорослому віці досить часто пов'язана $з$ перебудовою буденного життя і нерідко викликає гострі переживання. Не кожна людина готова до власної життєтворчості в контексті професійної переорієнтації та вибору професії. Ще більше ускладнюється цей процес після демобілізації. Для багатьох ветеранів оволодіти новою професією - це не простий виклик, пов'язаний з поверненням до мирного соціуму. Практичний досвід консультування ветеранів допоміг нам сформулювати припущення щодо ролі спрямованості на досягнення успіху і толерантності до невизначеності як головних рис, притаманних особам, які вдало самовизначаються після демобілізації. Травматичний досвід може стимулювати смисложиттєвий пошук, прагнення до особистісного зростання, що полегшує професійну переорієнтацію особистості. Щоб підтвердити або спростувати ці гіпотези, ми обрали такі методики:

тест-опитувальник вимірювання мотивації досягнення А. Мехрабіана (модифікація М. Магомед-Емінова); 


\section{методику визначення толерантності до невизначеності С. Баднера \\ (модифікація Г. Солдатової); \\ опитувальник посттравматичного зростання Р. Тедеші та Л. Калхун \\ (адаптація М. Магомед-Емінова); \\ тест смисложиттєвих орієнтацій Д. Леонтьєва.}

Для участі в пілотному дослідженні було запрошено 15 ветеранів, які вирішили змінити професію після демобілізації. Кожен з учасників отримав завдання за чотирма тестовими методиками, які потрібно було виконати і повернути досліднику. Методики пропонувались у зазначеному порядку, від менш емоційно насичених до таких, які потребують роздумів та осмислення.

Знаходження нової роботи або вибір нової професії в дорослому віці грунтується на усвідомленні власних потреб, які можуть бути задоволені в результаті виконання певної професійної діяльності. Спонукання до діяльності, активність, яка формується в особистості та проекується в соціальне життя, можна розглядати в контексті досягнення успіху або втечі, уникнення невдачі.

Для вивчення спрямованості мотивації учасників дослідження було використано Тестопитувальник А. Мехрабіана в модифікації М. Магомед-Емінова. За допомогою цього тесту можна діагностувати найбільш стійкі мотиви особистості, а саме прагнення успіху та уникнення невдач. Згідно з дослідницькою гіпотезою ветерани, які здійснили вторинне професійне самовизначення, мають мотивацію досягнення успіху.

За результатами вимірювання мотивації досягнень, серед ветеранів, які самовизначилися щодо професійного спрямування, є як ті, що обрали нову професію через мотив утечі від невдачі, так і ті, що переорієнтували свій професійний розвиток, зважаючи на мотив досягнення успіху. Отже, наша гіпотеза про те, що ветерани здійснюють вторинне професійне самовизначення, мотивуючись лише досягненням успіху, не підтвердилась. Саме тому видається недоцільним використовувати Тестопитувальник вимірювання мотивації досягнення А. Мехрабіана в масштабному емпіричному дослідженні, оскільки учасникам дослідження притаманні обидва типи мотивації досягнення, які, незважаючи на їхню полярну спрямованість, є рушійними в процесі особистісного професійного самовизначення.

Зміна професії в дорослому віці є викликом, який вимагає певних часових і фінансових витрат, зміни цінностей та життєвих орієнтирів. Обираючи нову професію, особистість “погоджується” на певну невизначеність у подальшому житті, пов'язану із фінансовим становищем, суспільним та особистісним прийняттям. Щоб підтвердити або спростувати гіпотезу про те, що із вторинним професійним самовизначенням тісно пов'язана така риса особистості, як толерантність до невизначеності, ми використали методику С. Баднера. Бути толерантним до невизначеності означає бути відкритим до нового досвіду, гнучким у використанні запропонованих життям можливостей, готовим витримувати смислову невизначеність власного життя та кризові прояви. Тому бралося до уваги те, що учасниками нашого дослідження були ветерани АТО, особи, які брали участь у бойових діях, для яких певний період життя був пов'язаний із зміною професійної активності, виходом із звичного соціального оточення, розумінням можливості втрати власного життя та втрати друзів. Зрозуміло, що така небуденна перебудова зовнішнього світу могла спричинити певні внутрішні особистісні зміни, сприяти формуванню нових рис особистості, які б допомагали їй більш ефективно проходити через надзвичайно складні життєві обставини. Отже, така особистісна риса, як толерантність до невизначеності, на нашу думку, може бути притаманною особам, які мали досвід травматичних подій, і ця риса є однією із провідних у процесі професійного самовизначення ветерана.

Зазначимо, що оригінальна методика С. Баднера у своїй назві фокусується на вивченні “інтолерантності” до невизначеності, хоч адаптована методика Г. Солдатової, яку ми використовуємо в дослідженні, у своїй назві акцентує увагу на толерантності. Вільний переклад назви методики С. Баднера вплинув і на умовний розподіл результатів на рівні, де високий бал результатів демонструє високий рівень інтолерантності, а низький - високий рівень толерантності, відповідно.

Згідно з результатами проведених вимірювань лише 20\% ветеранів нашої специфічної вибірки мають низький рівень толерантності до невизначеності, тоді як решта - високий (40\%) i середній (40\%). Отож можемо вважати методику визначення толерантності до невизначеності С. Баднера такою, що може бути в подальшому використана в масштабному дослідженні.

Щоб підтвердити або спростувати гіпотезу про зв'язок між вторинним професійним самовизначенням ветерана і його посттравматичним зростанням, було використано Опитувальник посттравматичного зростання, розроблений Р. Тедеші і Л. Калхаун та адаптований М. МагомедЕміновим. Ця методика дає змогу виміряти рівень посттравматичного зростання особистості, яка 
пройшла через надскладні життєві обставини. Феномен посттравматичного зростання є позитивним результатом проходження через складні життєві обставини і спостерігається у частини учасників екстремальних подій.

Результати діагностики за допомогою Опитувальника посттравматичного зростання показало, що 60\% учасників дослідження мають високий рівень посттравматичного зростання. Такий високий відсоток зростання пояснюється тим, що для дослідження було сформовано специфічну вибірку лише 3 тих ветеранів, які виявили готовність до професійної переорієнтації та більш повної самореалізації. При цьому 33,3\% учасників продемонстрували середній рівень посттравматичного зростання і 6,7\% низький, відповідно.

Потребують спеціального аналізу й окремі шкали методики, а саме: шкала “Нові можливості”, шкала “Сила особистості”, шкала "Підвищення якості життя”. Вторинне професійне спрямування ми пов'язуємо насамперед з результатами, отриманими за шкалою “Нові можливості”. За цією шкалою високий рівень можливостей демонструє переважна більшість учасників (66,5\%), тоді як на середньому рівні перебуває одна третина (33,5\%). Прикметно, що низький рівень за цією шкалою не продемонстрував жоден учасник дослідження.

За шкалою “Сила особистості” 46,7\% учасників продемонстрували високий рівень, 40\% середній і 13,3\% - низький. Отже, майже половина учасників дослідження виявляє рішучість у протистоянні зовнішнім впливам, керуючись власними прагненнями та потребами.

За шкалою "Підвищення цінності життя" у 53,4\% респондентів виявлено високий рівень, у 33,3\% - середній і у 13,3\% - низький. Ця шкала відображає усвідомлене ставлення ветеранів до власного життя як найвищої цінності, здатної сфокусувати цілепокладання, пріоритетність та діяльність людини згідно з їі власними прагненнями, зважаючи на обмеженість часу життя.

Отже, згідно з результатами вимірювання, підтвердилася гіпотеза про зв'язок між процесом вторинного професійного самовизначення ветерана і посттравматичним зростанням як результатом інтеграції набутого травматичного досвіду, а тому ми плануємо в подальшому використовувати Опитувальник посттравматичного зростання як цілком надійну методику в масштабному емпіричному дослідженні.

Зосередження уваги на осмисленні ветеранами власного життя та вимірювання цих показників за допомогою Методики посттравматичного зростання наближають наше дослідження до вивчення життєвих сенсів особистості як таких, що можуть мати вплив на професійне самовизначення учасників дослідження. Смисложиттєві орієнтації - це комплекс особистісних сенсів, якими особистість керується у власному просторі життя, організовуючи свою життєдіяльність та плануючи, “проектуючи" власне майбутнє. Поняття “професійне самовизначення” ми пов'язуємо 3 особистісними смислами людини, оскільки саме вони задають напрям пошуку та допомагають ій осягнути сенс професійної діяльності, яку вона обирає в результаті професійного самовизначення. Саме тому завершальним етапом пілотного дослідження стало застосування Тесту смисложиттєвих орієнтацій як відповідної до наших дослідницьких завдань методики.

Тест смисложиттєвих орієнтацій Д. Леонтьєва, що враховує загальний показник осмисленості життя, об'єднує п'ять шкал, які відображають смисложиттєві орієнтації особистості (життєві цілі, процес життя, результативність життя) та аспекти локусу контролю (локус-контроль - Я і локусконтроль - життя). Опишемо відтак більш детально ці шкали та розглянемо результати вимірювання.

Високий рівень усвідомлення життєвих цілей, що свідчить про наявність в особистості осмислених життєвих перспектив, продемонструвала значна частина учасників дослідження (40\%), стільки ж (40\%) - середній рівень і ще $20 \%$ - низький.

Схожі результати виявлено і щодо емоційної насиченості життя: високий рівень сприйняття особистістю власного життя як осмисленого, цікавого, наповненого зафіксовано у 40\% респондентів, середній - у такої ж кількості (40\%), низький - у 20\%.

Результати, отримані за шкалою “Результативність життя”, показали, що позитивно оцінюють власну самореалізованість $40 \%$ ветеранів, на середньому рівні цей показник так само у $40 \%$, на низькому - у $20 \%$.

Серед тих, хто усвідомлює себе сильною особистістю, яка має достатній рівень свободи, щоб робити життєвий вибір та будувати власне життя відповідно до своїх цілей та особистісних смислів, високий рівень продемонстрували $33,3 \%$ учасників, середній - 53,3\%, низький - 13,4\%.

Обнадійливими є дані щодо здатності учасників контролювати власне життя, приймати рішення та втілювати їх. Високий рівень - у 66,6\%, середній - у 20\%, низький - у 13,4\% ветеранів. 
3 огляду на отримані результати вимірювання вважаємо, що Тест смисложиттєвих орієнтацій Д. Леонтьєва відображає значущі для нашого дослідження результати і може бути в подальшому використаний у масштабному експериментальному дослідженні.

Висновки та перспективи подальших досліджень. Результати проведеного пілотного дослідження показали, що ветерани, які здійснили вторинне професійне самовизначення, мають різнобічну мотиваційну спрямованість, а саме мотивацію досягнення успіху і мотивацію уникнення невдач. Тому діагностування мотиваційної спрямованості на досягнення успіху або втечу від невдач не можна розглядати як суттєвий показник професійного самовизначення. Отож ми не плануємо в подальшому використовувати Тест-опитувальник вимірювання мотивації досягнення А. Мехрабіана (адаптація М. Магомед-Емінова) у масштабному емпіричному дослідженні.

Підтвердили свою результативність такі діагностичні заходи, як вивчення толерантності до невизначеності, 3'ясування готовності до посттравматичного зростання та визначення смисложиттєвих орієнтацій. Ці показники можна вважати чинниками вторинного самовизначення ветеранів, а відповідні апробовані методики доцільно використовувати в подальших дослідженнях.

Питання вторинного професійного самовизначення ветеранів АТО потребує не лише кількісного, а і якісного дослідження як такого, що допоможе зрозуміти глибинні сенси особистості, що просувається шляхом професійної перебудови. Вторинне професійне самовизначення дорослої людини, і зокрема ветерана, потребує деталізованого розгляду, урахування особистісного досвіду, суб'єктивних сенсів та інтерпретацій. Саме тому наступним кроком у вирішенні завдань дисертаційного дослідження буде проведення глибинного інтерв'ю з ветеранами АТО, аби з'ясувати причини, які спонукають їх обирати новий професійний шлях. Важливим є також дослідження перешкод на шляху саморозвитку особистості та можливостей само проектування в новій професійній реальності.

\section{Список використаних джерел}

Гусєв, А. І. (2009). Толерантність до невизначеності як чинник розвитку ідентичності особистості. (Дис. канд. психол. наук). Університет менеджменту освіти НАПН України, Київ.

Болотова, А. К., \& Макарова, И.В. (2001). Тест-опросник измерения мотивации достижения (модификация опросника А. Мехрабиана). В Прикладная психология (с. 174-178). Москва: Аспект Пресс.

Леонтьев, Д. А. (2000). Тест смысложизненных ориентаций. (СЖО). Москва: Смысл. $3(5), 2-6$.

Лушин, П. В. (2016). Неопределенность, которую не толерируют. Теория и практика психотерапии,

Магомед-Эминов, М.Ш. (2007). Опросник посттравматического роста. В Позитивная психология человека. От психологии субъекта к психологии бытия. т. 1 (с. 548-551). Москва: Парф.

Солдатова, Г. У., Шайгерова, Л. А., Прокофьева, Т. Ю. \& Кравцова, О. А. (2008). Методика определения толерантности к неопределенности. В Психодиагностика толерантности личности (с. 94-97). Москва: Смысл.

Титаренко, Т.М. (2004). Життєві домагання особистості: феноменологічний та структурнофункціональний підходи. Психологія особистості, 4, 128-145. Взято 3 http://pis.tneu.edu.ua/index.php/ uapis/article/view/166/166.

Титаренко, Т. М. (2016). Личностное здоровье в условиях травматизации: поиск путей восстановления. Теория и практика психотерапии, 3 (5), 7-13.

Титаренко, Т. М. (2017). Стратегії сприяння посттравматичному зростанню особистості. Психологічні науки: проблеми і здобутки, 1 (10), 217-232. Взято з http://lib.iitta.gov.ua/709888/.

\section{References}

Husiev, A. (2009). Tolerantnist do nevyznachenosti yak faktor rozvytku identychnosty osobystosti. (Dys. ... kand. psykhol. Nauk) [Tolerance for uncertainty as a factor in the development of personal identity: Thesis ... Ph. D. in Psychology]. Universytet menedzhmentu osvity NAPN Ukrainy, Kyiv. (in Ukrainian)

Bolotova, A. K., \& Makarova, I. V. (2001). Test-oprosnik izmereniya motivatsii dostizheniya (modifikatsiya oprosnika A. Mekhrabiana) [Measurement of the achievement motivation (modification of Mehrabian's questionnaire]. Prikladnaya psikhologiya (pp. 174-178). Moscow: Aspekt Press. (in Russian)

Leontyev, D. A. (2000). Test smyslozhiznennykh orientatsiy [Test of life-meaning orientations]. Moscow: Smysl. (in Russian)

Lushin, P. V. (2016). Neopredelennost, kotoruyu ne toleriruyut [Uncertainty which is not tolerated]. Teoriya $i$ praktika psikhoterapii, 3 (5), 2-6. (in Russian) 
Magomed-Eminov, M. Sh. (2007). Oprosnik posttravmaticheskogo rosta [Post-traumatic growth questionnaire]. In Pozitivnaya psikhologiya cheloveka. Ot psikhologii subyekta k psykhologii bytiya, vol. 1, pp. 548-551. Moscow: Parf. (in Russian)

Soldatova, H. U., Shaygerova, L. A., Prokofyeva, T. Y. \&, Kravtsova, O. A. (2008). Metodika opredeleniya tolerantnosti $\mathrm{k}$ neopredelennosti [Psychodiagnostics of personality tolerance]. In Psikhodiagnostika tolerantnosti lichnosti (pp. 94-97). Moscow: Smysl. (in Russian)

Tytarenko, T. M. (2004). Zhyttievi domahannia osobystosti: fenomenolohichnyi ta strukturno-funktsionalnyi pidkhody [Life aspiration of personality: phenomenological and structural-functional approaches]. Psykholohiya osobystosti, 4, 128-145. Retrived from http://pis.tneu.edu.ua/index.php/ uapis/article/view/166/166. (in Ukrainian)

Tytarenko, T. M. (2016). Lichnostnoye zdorovye v usloviyakh travmatizatsii: poisk putey vosstanovleniya [Personal health in conditions of trauma: finding ways to recover]. Teoriya i praktika psikhoterapii, 3(5), 7-13. (in Russian)

Tytarenko, T. M. (2017). Stratehii spryiannia posttravmatychnomu zrostanniu osobystosti [Strategies to promote post-traumatic personality development]. Psykholohichni nauky: problemy i zdobutky, 1(10), 217-232. Retrived from http://lib.iitta.gov.ua/709888/ (in Ukrainian) 